\title{
Need for Speed onto Internet Clashes with Journalistic Values
}

by Scott Reinardy

Interviews with U.S. newspaper journalists reveal
that along with online initatives, newsroooms are
experiencing organizational transformation. Young
journalists are driving it and have adopted the online
initiatives as older journalists continue to struggle.

$\mathrm{N}$ ewspaper journalists are angry and Kiyoshi Martinez might know why. After about five months, the 23-year-old Martinez quit his newspaper job and accepted a communications position with the Illinois Senate Republicans. Martinez did not quit his Web editor position at the 22nd Century Media newspaper group because he was particularly discontent in his job. He earned undergraduate and graduate degrees in journalism, and while in college he was committed to a career in newspapers. However, what he started to notice in his work environment, and more importantly, the industry, persuaded Martinez to change career paths. ${ }^{1}$

I was thinking about where I was going to be after my first job. Would I still be in the industry 10 years from now? I reached the conclusion that it wasn't a place for me, and it wasn't very stable.

Industry news of diminishing profits, job reductions, increased workloads, an emphasis on hyperlocal news and a lack of leadership during this transitional time persuaded Martinez that he would probably never become the hard-core investigative journalist he desired.

But even after he left his newspaper job, Martinez wondered if others were equally frustrated with the profession. So, Martinez developed a Web site that al-

Reindary is an assistant professor in the William Allen White School of Journalism and Mass Communication at the University of Kansas. 
lowed journalists to express their displeasure. Angryjournalist.com was launched Feb. 10, 2008, and by August 2009 there were more than 9,000 postings. ${ }^{3}$

The State of the Media 2009 annual report said about 5,000 full-time journalism jobs disappeared in 2008. ${ }^{4}$ Since 2001, cuts have reduced the newspaper workforce by about 16 percent or about 9,000 jobs. Between 2005 to 2007 newspaper stocks lost 42 percent of their value. In 2008, the scenario grew much worse as newspapers dropped 83 percent of their remaining value. Also in 2008, advertising revenue continued its decline (down 23 percent since 2006) as well as circulation (down 4.6 percent in 2008). ${ }^{5}$

And while newspapers have continued to embrace a more active online news strategy, ${ }^{6} 45$ percent of journalists say the Internet will weaken rather then strengthen (34 percent) traditional journalistic values. ${ }^{7}$ However, older journalists are more likely than younger journalists to say the Internet will weaken values. ${ }^{8}$

Reinardy's $\mathrm{s}^{9}$ examination of burnout, life issues and job satisfaction of newspaper journalists has demonstrated that, while news workers wrestle with the altering landscape of the newspaper industry, they continue to be committed to their work. However, moderate rates of burnout, conflicts between work and family, lack of organizational support, work overload and tenuous job satisfaction continue to challenge that commitment. Reinardy ${ }^{10}$ reported that nearly 26 percent of news workers indicated they intended to leave newspapers, citing industry issues (quality of journalism) and job dissatisfaction as the primary reasons. Comparably, Weaver et $a . .^{11}$ reported in their study that 17 percent of journalists expressed intentions to leave newspapers within five years. Reinardy speculates that intentions to depart are a result of diminished journalistic standards instigated by the drive to increase profits and readership.

As newspaper organizations attempt to adapt to the recent technological and economic alterations, news workers have been expected to adapt as well. Many are being asked to do more (writing stories or shooting video for the Web, compiling photo galleries, blogging, etc.) with less (layoffs, buyouts, hiring freezes, long delays in filling positions, etc.). And, newsroom strategies have shifted from a once-a-day deadline for the morning edition to a $24 / 7$ continuous deadline. But when news organizations drastically alter their strategic plan, how does it affect the news worker?

Rosten, ${ }^{12}$ Breed, ${ }^{13}$ Schudson, ${ }^{14}$ Tuchman, ${ }^{15}$ Singer,${ }^{16}$ Gade ${ }^{17}$ and others extensively examined newsworkers in their newsrooms in an attempt to test organizational development theory. In an effort to advance the previous research, this study will specifically examine the newsroom from a renewed perspective. As newspapers shift from the paper product to an electronic format, transitional obstacles are apparent. The top-down directive to incorporate online-friendly aspects of news-i.e. stories immediately posted on the Web, video clips, photo slideshows, reporter blogs-has created a dramatic shift in news strategy. Newspaper reporters, editors, copy editors, photographers, page designers, graphic artists and managers have been instructed to reinvent how they do their work. ${ }^{18}$ 
And with the reduction in workforce and increased competition, news in the 24-hour newspaper newsroom has become a more taxing proposition. ${ }^{19}$

The purpose of this study is to examine how newspaper journalists are adapting to the organizational shift in news strategy created by shrinking newsrooms, the Internet and generational attitudes. This study builds upon the rich history of newspaper organizational research founded by Rosten ${ }^{20}$ and Breed ${ }^{21}$, expanded by Schudson ${ }^{22}$ and continued by Singer ${ }^{23}$ and Gade ${ }^{24}$, among others.

\section{Literature Review}

In 1937, Rosten, a University of Chicago doctoral graduate, surveyed Washington newspaper correspondents and reported that the correspondents worked to appease their editors. ${ }^{25}$ A story that did not fulfill the editor's news perspective was buried in the newspaper, drastically trimmed or killed altogether. Rosten discussed the newsroom societal norms as established by management but failed to delve much deeper into the overall schematic that cultivates newsroom culture. ${ }^{26}$

Breed significantly expounded on Rosten's work, plunging deeply into newsroom sociology in an attempt to discover the routines and practices of reporters and editors. ${ }^{27}$ Generally speaking, he said newsroom employees learned through "osmosis," 28 and young reporters were internally encouraged to adhere to newsroom norms for several reasons-better story play, promotions, pay raises, better opportunities at other newspapers and occasionally the opportunity to break from the norms to write stories that did not fall into the narrow chasm of what editors determined "newsworthy." 29

As important as Breed's work was, he did not look beyond the newsroom when discussing the formulation of newsroom norms. His inside-out approach assumed the individuals worked in a newsroom vacuum void of outside interference. Schudson, however, worked outside-in to examine a multitude of external influences that molded individual perceptions of news work as well as the formulation of newsroom routines. ${ }^{30}$

Schudson discussed the origins of the "adversary press" that appeared to have evolved throughout the 1960s ${ }^{31}$ The general belief at that time was that the press had become adversarial while challenging authoritative institutions, primarily government and business. Schudson said, although that might be true, the adversarial disposition of the media was as reflective of society as it was directing society. ${ }^{32}$ Schudson questioned whether the press influenced society or if society influenced the individuals who represent the press. ${ }^{33}$

Tuchman further developed that idea, saying there are a multitude of influences that cast a reporter's perspective, leading back to childhood.$^{34}$ Religion, culture, environment, relationships with parents, education, economics, geographic location and other influences impact every person. When a young reporter begins working in a newsroom, some of his or her personal values 
may conflict with newsroom norms. Compromises are made to fit individual perceptions into the cultural structure. Of course, similar to the observations of Rosten, ${ }^{35}$ Breed $^{36}$ and others, a story still can be buried, killed or trimmed if it fails to fall inside the newsroom's prescribed boundaries of newsworthiness.

In the examination of newsroom societies most have agreed that norms are not formally or even consciously established. The acceptability of what is news, what is a journalist's job, newsworthiness, media integrity, journalism objectivity and what is considered appropriate journalistic practice are elusive and confounding propositions. Newsrooms are groups and similar to other groups they take their lead from the leaders. But there are no leaders without followers and most newsroom employees gladly follow. Arguably, it's in the reporter's best interest to follow. Failure to abide by the knowable, yet unspoken, rules is potentially a path to a dead-end career.

Shoemaker and Reese acknowledge that individuals conform to organizational norms, and that as social creatures, people will follow patterns of action that they did not create, thus developing a groupthink mentality. ${ }^{37}$ However, they contend that an individual's role perspective will change whenever his or her position changes in the organization. They continue to say that news workers working in different roles with different agendas need to reconcile their differences. "When push comes to shove," they write, "individual workers and their routines must be subordinated to the larger organization and its goals."

In part, Singer tested that notion with her examination of a "sharing of news staffs, technologies, products and geography" between newspapers and television stations working in a convergence relationship. ${ }^{39}$ She specifically studied the challenges to traditional journalistic practices convergence created for newspaper journalists and their long-held beliefs and values. She said the convergence experience created a better understanding of the responsibilities of the individuals in different newsrooms. She also speculated that there would be some converging of newsroom norms. ${ }^{40}$

While Singer examined a narrow scope of an organizational shift in newsrooms, Gade took a macro approach to managerial change. ${ }^{41} \mathrm{He}$ argued that change initiatives were enacted to alter the culture of the newsroom, creating an environment that was more marketable and interactive with the readers. Managers used their newsrooms as laboratories to experiment with new change initiatives, such as the "team" system of reporting and "reader-driven" or "market-driven" journalism. Gade reported that those initiatives were-depending upon whom you ask-either "news standards of excellence or points of controversy and resistance." ${ }^{2}$ While management believed newsroom employees generally understood thenewspaper's core values and mission, those employees were not as sure of those missions and values. ${ }^{43}$

Although Reinardy ${ }^{44}$ did not examine specific newsroom alterations and their affects on news workers, he studied the dynamics that construct satisfaction and dissatisfaction among newspaper journalists. Reinardy demonstrated that while work-family conflict, job demands and role overload were predictors 
of dissatisfaction, perceived organizational support was a significant predictor of satisfaction. Journalists said encouragement and support from managers and colleagues bolstered their satisfaction. Those intending to leave newspapers (26 percent) were frustrated with the lack of managerial support and the diminished commitment to journalistic integrity.

\section{Organizational Development Theory}

Lewin ${ }^{45}$ was one of the first to develop a model under the premise of organizational development theory. His "unfreezing, change, refreezing" process is based on the notion that an organization needs to prepare for change, implement change and create acceptance of the change in order to return to pre-change comfort levels. Lewin's ideologies of organizational development hold up in principle but adaptations and modifications have been plenty. For instance, Bergquist ${ }^{46}$ suggests that a majority of organizational theorists have framed organizations as pendulum-swinging apparatuses that emphasize "simplicity in motion" and stability. During chaotic times, organizations seek balance by returning to their preceding form and function. For the newspaper industry, that is no longer possible. Between technological transformations and diminished personnel, going back is not an option.

In Gade and Perry's four-year study of the "cultural transformation" of the St. Louis Post-Dispatch, they reported newsroom employees were initially optimistic about the change in 1997 but that turned to "broad-based dissatisfaction" by 2000. ${ }^{47}$ The authors specifically examined the shift from reporter beats to a "team" system and a "public journalism" initiative employed by incoming editor Cole C. Campbell. Gade and Perry concluded that in an effort 
to increase readership, the division between the news side and business side had been diminished. ${ }^{48}$

Gade identified a clear delineation between the perceptions of management and journalists in his extensive study. ${ }^{49} \mathrm{He}$ wrote:

In short, management believes it has 'managed' the change process in general accordance with theory. Rank-and-file, on the other hand, feel more victims of change than participants in it..$^{50}$

\section{Research Questions}

The current changing landscape does not involve tweaking the newsroom structure or adopting minor modifications. Newspapers are undergoing major renovations in style, substance and philosophy. This study will build on previous organizational development work by examining the following research questions:

RQ1:

Have newspaper strategies changed in recent years? If so, how?

RQ2:

What has been the result of newsroom change?

RQ3:

Have age and years of experience affected how journalists have adapted to the newsroom changes? If so, how?

\section{Method}

The Editor \& Publisher International Yearbook (2006) was used to extract e-mail contacts at 1,452 U.S. daily newspapers. Most of the contacts were managing editors. An e-mail was then sent to the managing editors in January 2007, explaining the study and requesting the staff e-mail lists of their full-time newspaper newsroom employees. If e-mail addresses of managing editors were not available, the recruitment e-mail was sent to a general news mailbox.

Of the 1,452 e-mails distributed, 338 were dead accounts. Of the remaining 1,114 e-mails, 74 newspaper representatives responded and provided access to their staffs' e-mail lists. From that list, a database of 2,791 journalists was established.

An explanatory e-mail was sent to 2,791 full-time newsroom staffers in February 2008. The e-mail included a Web site providing the results of previous research conducted by the researcher. The e-mail also included an invitation for volunteers willing to be interviewed by the researcher. 
Forty-eight respondents contacted the researcher and were interviewed for this study. The respondents were assured they would not be identified by name or news organization. Before the interview, via e-mail the respondents provided their age, gender, newspaper circulation size, years of newspaper experience, job title, marital status and parental responsibilities for children living at home.

The interviews were conducted in February and March 2008, and lasted between 10 and 30 minutes. Confidentiality was provided so the respondents could feel free to speak openly about their news organizations. Respondents were asked a standard list of eight questions that addressed issues such as stress, news strategy, additional training, job satisfaction, job reduction at the place of employment, long-term plans, the future of newspapers and generational issues that might be prevalent in their newsroom. An example of questions includes, "What is the most stressful part of your job? How has your organization's news strategy recently changed?" and "Are there differences in how journalism is conducted today than earlier in your career? If so, what are those differences?"

Interviews were used for this study in an effort to better explain how changes in news strategies have affected news workers. Wimmer and Dominick ${ }^{51}$ contend that interviews provide an incredible wealth of information and insight. Additionally, interviews provide more accurate responses to sensitive issues that other methods, such as surveys, would not. It can be argued that the changing tide in newspaper newsrooms can certainly be a sensitive issue for some.

\section{Results}

Respondents represented 23 newspapers from 11 states throughout the country. Twenty-seven males and 21 females participated in the interviews. The average age of the respondents was 44.8 years, and they averaged 21 years of newspaper journalism experience. Twenty-nine were married and 18 had parental responsibilities. The Sunday circulation size of the newspapers ranged from 5,000 to 1.6 million. The respondents included 12 reporters, eight local news editors, seven copy editors, six sports writers, five editors/managing editors, four columnists, two photographers, two page designers and two editorial page writers.

\section{Change in news strategies was the focus of RQ1.}

Overwhelmingly, respondents said the increased Web presence was the primary emphasis of newsroom initiatives in 2008 (42 of 48 participants in this study said Web). And although catchphrases "multimedia" and "new media" were commonplace during the interviews, there were different strategies of implementation. While some newspapers were using the Web as a place for breaking news, others were using it as a place to enhance stories with photo galleries, streaming video and reporter blogs. A52-year-old reporter said, "We're in a Web world now so everything I do, I do twice and sometimes three times. 
You always feel like you're serving two or three masters." ${ }^{52}$ A 53-year-old local editor said,

We've been told we're changing our emphasis from being a newspaper with a Web site to being a Web site with a newspaper... We count Web hits more than we count circulation..$^{53}$

Web also drives content in the morning newspaper. Several respondents said occasionally Web stories that would traditionally be buried inside the newspaper have floated their way to the front page because of their electronic popularity. A 45-year-old copy editor said the mantra at his newspaper is to break news on the Web and explain it in the print edition.

There have been a couple of crazy days when your front page the next day is five stories that are all local and three have been broken on the Web in the afternoon, which is actually pretty cool. ${ }^{54}$

A 53-year-old local editor said management's constant Web surveillance has become the new edict for determining what is news.

They're constantly checking which stories get the most story chat action and the most hits. We've had stories go from being an inside local story to being an $A 1$ story all because of the activity online. ${ }^{55}$

A majority of journalists said they have not received formal training for using video cameras, posting to the Web or even the differences in writing a Web story compared to a traditional newspaper story. Some, however, said along with the Web strategy their newspapers have reignited an emphasis for hard news and hyperlocal reporting. One obvious drawback is the additional Web responsibilities. Even a 62-year-old editor recognized the uncomfortable juxtaposition, saying,

What I'm doing now is having meetings with each staff to talk about our move to a 24-hour-a-day, 7-day-a-week, 52-week-a-year newsroom. And we're going to have to it with current resources. ${ }^{56}$

In answering RQ2, concerns about journalistic standards appeared to be the most prominent issue resulting from newsroom adaptations.

However, two separate issues defined standards - the process of doing the work and the quality of the work itself. Although related, and perhaps even tangential, some participants in this study outlined distinctions. A 31-year-old managing editor said: 
When I was in school, it was pounded in my head you have to have two to three sources and you don't do this, you don't do that. I don't really see that in journalism schools right now. What I see them coming out with is a lot of skills. They can go take pictures and write and do video and a lot of the Web stuff. ${ }^{57}$

The process of producing materials for the Web was prominently discussed among many of the participants. The rush to publish online encouraged shortcuts in reporting and editing and appeared to be counterintuitive to traditional journalistic standards. A 59-year-old copy editor at a 40,000-circulation newspaper said,

You're really not a copy editor anymore; you're becoming more of a technician. It's like forget about layout, forget about good grammar, forget about kicking back stories if you find something really wrong with them. ${ }^{58}$

Another copy editor, who is 45 and working at a 275,000-circulation newspaper, said:

Right now we don't have any copy editors assigned to copy edit anything before it goes to the Web, which can present problems with headlines that are wrong or stories that are wrong or people who are dead in stories and are alive. ${ }^{59}$

Other journalists said the quick and easy Web format is watering down good journalism and some editors are even willing to compromise quality for immediacy. A day before the interview, a 55-year-old page designer attended a meeting where the staff of the 128,000-circulation newspaper were told more Web emphasis means:

'There will be more errors, we will do less editing, and we are willing to live with that.' There are going to be more compromises in editing to get more onto the Web. . . . . I think the things that inspired someone my age to become a journalist are going away and I think that's too bad. ${ }^{60}$

According to several participants in the study, the change in process inversely affects quality. That same 38-year-old reporter continued: "It's almost like you're in television and newspapers. Inevitably, when you're doing your first job, it takes away from your second job."61

A 49-year-old news reporter agreed, saying:

They want us to do shorter, quicker pieces that really don't have a lot of depth. They're interested in more positive stories. I might as well get a job as a publicist and make some money. ${ }^{62}$ 
A substantial group of respondents was disenchanted with the blatant acceptability of minimal journalistic standards.

A 37-year-old sports writer said:

I feel like they've decided to lower the bar. There's a lot lower standard asked of us by the publishers; get enough out to wrap up our advertising and make people happy buying the paper. ${ }^{63}$

A 26-year-old copy editor agreed:

I really care what newspapers stand for... Our problem is we still pay lip service to caring about what we used to care about when we look the other way and cut jobs and cut the budget. ${ }^{64}$

Some participants said the reduction in quality could lead to deeper, more disconcerting issues. A 47-year-old reporter said:

I absolutely believe that we have to adjust and change things as we go along but I'm really troubled by the loss of integrity in the news that I see happening at the same time. ${ }^{65}$

$R Q 3$ asks if age and experience has affected how journalists have adapted to the newsroom renovations.

In this study, 19 of the respondents were 45 and younger, including 11 who were under 35 . Several veteran journalists said their staffs have gotten much younger in the past few years, and with that, the culture is changing. One53-yearold lamented, "The young people are taking over the friggin' newsroom. They laugh at us (about technological skills/knowledge) and it pisses me off." ${ }^{\prime 66}$

Technology was a sore subject for both young and old. The younger generation (45 and younger) expressed their frustration with the older generation's lack of technological savvy, while the veterans generally said the younger journalists lowered the journalistic bar by relying too heavily on the Internet. "There's a higher standard for tone of language (formality) among people who've been here a long time compared to younger people," a 48 -year-old copy chief said. ${ }^{67}$

Others, mostly veterans, suggested that the younger generation is not interested in what has traditionally been identified as hard news. A 49-year-old assistant editor said:

Our editor doesn't like to read and thinks Britney Spears is the most interesting thing in the paper. He refers to the government stuff as 'that boring stuff.' 68 
Meanwhile, several younger journalists said the veterans struggled to "get it," and their pessimism about the future of journalism is not encouraging. Addressing the change in coverage, a 36-year-old city editor said:

Yeah, it's sad, you know, let's all cry a tear for the changing times but, you know, frankly some of those things probably should have been covered less in the old days anyway. It was because we had more people and more time and not enough imagination we wound up covering those things instead of doing work that would have safeguarded us against cutting back in the first place. ${ }^{69}$

Routinely younger respondents said they were more innovative than the older generation in telling stories by using new technologies. A 25-year-old page designer said:

The younger person might be thinking of it in a different way, whether that's including a video with it or trying to come up with a new way of reporting that story. I think a lot of the older generation of journalists often are arguing that 'this is the way we've done things and we need to keep doing it that way. ${ }^{70}$

Most of the veteran journalists said they are willing to adapt, and many have done so, but their primary concern is sacrificing quality journalism for faster, softer, inaccurate, piecemeal Web nuggets. "I'm not fighting the trends," a 47-year-old reporter said. "I'm going along and doing what I need to do keep my job. One of those young people could run right over me." ${ }^{\prime 11}$ Meanwhile, others continue to struggle with the transformation. A 55-year-old reporter/editor said:

There are people who are as old as me who, when they're asked to sit in on a training session for new media and use things like video and doing things on the fly for the Web edition, are rolling their eyes and struggling with it. ${ }^{72}$

\section{Conclusions}

Generally speaking, what the interviews have revealed is that work overload remains a primary issue of contention in light of reduced numbers in the newsroom and expansive Web initiatives. Although attempting to do more with less is nothing new to the newspaper industry, ${ }^{73}$ the alteration of news strategy adds a confounding dimension, particularly for veteran journalists. ${ }^{74}$ The change is not simply a technological adaptation to online mechanisms but a journalistic philosophy that is being manipulated by the Web. However, as many respondents have noted, that comes with a price. Sacrifices in accuracy, good writing and sourcing are more acceptable than with traditional, printonly newspaper journalism. Because time is of the essence with online stories, 
getting it first and getting it fast appear to supersede other more traditional core newspaper values. The findings appear to confirm previous work where older journalists (55 and older) said the Web weakens rather than strengthens journalism. ${ }^{75}$

Several veterans in this study expressed a desire to leave newspaper journalism but said their options were limited. One respondent said she was heartbroken over the changes in the industry and began to cry during the interview. Others said they felt trapped because they needed to retain health insurance and freelancing or other possible career changes were too financially risky. While they have remained steadfast in the journalistic mission, they said their newspaper organization has not. For the individual and the organization the mission has changed, but for many in this study the change is not necessarily good or acceptable for traditional journalism.

Rosten $^{76}$, Breed $^{77}$ and others acknowledge that, although not formally documented by management, established newsroom norms influence the behavior of incoming colleagues. But what happens when undocumented norms collide with a new managerial decree that is embraced by the younger generation and perhaps runs contrary to the established norms?

In the footsteps of Schudsen's adversarial press, this study demonstrates that the younger generation has quickly adopted the revised news strategy and is initiating the change. ${ }^{78}$ In their wake, veteran journalists struggle with the technology, online journalism formats, and their own place in the organization. Indications are that the newsroom culture is shifting dramatically, and those who had previously set the norms are now subjected to new norms directed by management and instituted by subordinates. Similar to Gade's finding, it appears there's a group of journalists who seem to feel more like victims of change rather than participants in it. ${ }^{79}$

Although veteran journalists have experienced newsroom alterations in the past (typewriters to computers; pagination systems; the advent of literary journalism), the shift to Web obligations is different. For veterans, the immediacy of online distribution undermines the very premise of producing good journalism. Journalists are a committed lot and expect the quality of their work to be appreciated. Traditionally, journalism has been a "calling" for those inclined to do newspaper work. In their book, Good Work, Gardner, Csikszentmihalyi and Damon write, "In a field where good work is frequently marginalized and trashy work is frequently rewarded, it is not easy to sustain a mission that reflects the domain's best traditions." ${ }^{80}$ So perhaps the discontent among veterans is not laden in technological intimidation or a loss of control of newsroom norms to the less experienced journalists. Maybe the real concerns lie in the loss of the very thing that enticed them into the newsroom to begin with, which could be a topic of future reseach.

This study has several limitations. Although interviews provide a wealth of information, the results cannot be generalized to the population of journalists. Also, because respondents volunteered to be interviewed, they could have been 
more motivated to vent or express their opinions that perhaps do not reflect their colleagues.

With all the changes occurring in newspaper newsrooms, it's no surprise the culture is changing as well. In light of shrinking newsrooms, technological advancements, increased workload, a shift in news strategy and the uncertainty of the industry, the organizational shift could continue for some time.

\section{Notes}

1. Martinez, interview, March 29, 2008.

2. Martinez, interview, March 29, 2008.

3. Angryjournalists.com, <http:/ / angryjournalist.com/> (13 August 2009).

4. Rick Edmonds, "The State of the News Media 2009: An annual report on American journalism," Pew Project for Excellence in Journalism, 16 March 2009, <http: / / www.stateofthenewsmedia. org/2009/narrative_newspapers_intro.php?media=4 (13 August 2009).

5. Edmonds, "The State of the News Media 2009," 2009.

6. Edmonds, "The State of the News Media 2009," 2009.

7. "Financial Woes Now Overshadow all Other Concerns for Journalists," The Pew

Research Center, (17 March 2008), <http://people-press.org/reports/display. php3?ReportID=403> (13 August 2009).

8. "Financial Woes Now Overshadow all Other Concerns for Journalists," 2008.

9. Scott Reinardy, "It's Gametime: The Maslach Burnout Inventory Measures Burnout of Sports Journalists," Journalism E Mass Communication Quarterly, 83 (2) (spring 2006):397-412; Scott Reinardy, "Satisfaction vs. Sacrifice: Sports Editors Assess the Influences of Life Issues on Job Satisfaction," Journalism \& Mass Communication Quarterly, 84 (1) (spring 2007): 105-121; Scott Reinardy, "Beyond Burnout: The Effects of Life Issues on Burnout Among Newspaper Sports Editors," Newspaper Research Journal, 29(2) (2008): 40-54; Scott Reinardy, "Beyond Satisfaction: Journalists Doubt Career Intentions as Organizational Support Diminishes and Job Satisfaction Decline," Atlantic Journal of Communication, 17(3) (2009): 126-139.

10. Reinardy, "Beyond Satisfaction," 2009.

11. David Weaver, Randal Beam, Bonnie Brownlee, Paul Voakes and Cleveland Wilhoit, The American Journalists in the 21st Century: U.S. News People at the Dawn of a New Millennium (Mahwah, NJ: Lawrence Erlbaum Associates, Inc., 2007).

12. Louis Rosten, The Washington Correspondents (NY: Harcourt, Brace and Company, 1937).

13. Warren W. Breed, "Social Control in the Newsroom: A Functional Analysis," Social Forces, 33 (1955): 326-335.

14. Michael M. Schudson, Discovering the News: A Social History of American Newspapers (NY: Basic Books, Inc., 1978).

15. Gaye G. Tuchman, Making News: The Study in the Construction of Reality (NY: The Free Press, 1978).

16. Jane Singer, "More than Ink-Stained Wretches: The Resocialization of Print Journalists in Converged Newsrooms," Journalism E Mass Communication Quarterly, 81 (winter 2004): 838-856.

17. Peter J. Gade, "Newspapers and Organizational Development: Management and Journalist Perceptions of Newsroom Cultural Change," Journalism Communication Monographs, 6 (2004): 5-55.

18. Frank Ahrens, "Gannett to Change its Papers' Approach," The Washington Post, November 7, (2006) Section D: 1.

19. "Financial Woes Now Overshadow all Other Concerns for Journalists," 2008.

20. Rosten, The Washington Correspondents.

21. Breed, "Social Control," 326-335. 
22. Schudson, Discovering the News.

23. Singer, "More than Ink-Stained Wretches," 838-856.

24. Gade, "Newspapers and Organizational Development," 5-55.

25. Rosten, The Washington Correspondents.

26. Rosten, The Washington Correspondents.

27. Breed, "Social Control," 326-335.

28. Breed, "Social Control," 328.

29. Breed, "Social Control," 326-335.

30. Schudson, Discovering the News.

31. Schudson, Discovering the News.

32. Shudson, Discovering the News.

33. Schudson, Discovering the News.

34. Tuchman, Making News: The Study in the Construction of Reality, 1978.

35. Rosten, The Washington Correspondents.

36. Breed, "Social Control, "326-335.

37. Pamela Shoemaker, \& Stephen Reese, Mediating the Message: Theories of Influences on Mass Media Content (NY: Longman Publishers, 1991).

38. Shoemaker \& Reese, Mediating the Message, 116.

39. Singer, "More than Ink-Stained Wretches," 838.

40. Singer, "More than Ink-Stained Wretches," 851.

41. Gade, "Newspapers and Organizational Development,"5-55.

42. Gade, "Newspapers and Organizational Development," 45.

43. Gade, "Newspapers and Organizational Development," 45.

44. Reinardy, "Beyond Satisfaction," 2009.

45. Kurt Lewin, "Frontiers in group dynamics: Concept, method and reality in social science: social equilibria and social change," Human Relations, 1 (June, 1947): 5-41.

46. William H. Bergquist, The Postmodern Organization: Mastering the Art of Irreversible Change (San Francisco: Jossey-Bass, 1993).

47. Peter J. Gade, \& Earnest L. Perry, "Changing the Newsroom Culture: A Four-Year Case Study of Organizational Development at the St. Louis Post-Dispatch," Journalism \& Mass Communication Quarterly, 80 (2003): 327-347.

48. Gade \& Perry, "Changing the Newsroom," 339.

49. Gade, "Newspapers and Organizational Development," 5-55.

50. Gade, "Newspapers and Organizational Development," 45.

51. Roger Wimmer \& Joseph Dominick, Mass Media Research: An Introduction (8th Edition)

(Belmont, CA: Thomson Higher Education, 2006).

52. Interview 44, March 14, 2008.

53. Interview 2, Feb. 29, 2008.

54. Interview 11, March 7, 2008.

55. Interview 2, 2008.

56. Interview 45, March 14, 2008.

57. Interview 19, March 10, 2008.

58. Interview 14, March 7, 2008.

59. Interview 11, March 7, 2008.

60. Interview 45, 2008.

61. Interviw 38, 2008.

62. Interview 12, March 7, 2008.

63. Interview 31, March 12, 2008.

64. Interview 9, March 5, 2008.

65. Interview 46, March 17, 2008.

66. Interview 2, Feb. 29, 2008. 
67. Interview 18, March 10, 2008.

68. Interview 10, March 7, 2008.

69. Interview 3, Feb. 29, 2008.

70. Interview 20, March 10, 2008.

71. Interview 46, 2008.

72. Interview 23, March 10, 2008.

73. "The State of the News Media 2008," 2008.

74. "Financial Woes Now Overshadow all Other Concerns for Journalists," 2008.

75. "Financial Woes Now Overshadow all Other Concerns for Journalists," 2008.

76. Rosten, The Washington Correspondents.

77. Breed, "Social Control," 326-335.

78. Schudson, Discovering the News.

79. Gade, "Newspapers and Organizational Development," 5-55.

80. Howard Gardner, Mihaly Csikszentmihalyi and William Damon, Good Work: When Excellence and Ethics Meet (NY: Basic Books, 2001) 170. 
Copyright of Newspaper Research Journal is the property of Newspaper Research Journal and its content may not be copied or emailed to multiple sites or posted to a listserv without the copyright holder's express written permission. However, users may print, download, or email articles for individual use. 